\section{High Frequency of Somatic Embryogenesis and Recover of Fertile Cucumber Plants}

\author{
Paula P. Chee \\ Molecular Biology Research, The Upjohn Company, 301 Henrietta \\ Street, Kalamazoo, MI 49007
}

Additional index words. Cucumis sativus, plant tissue culture, regeneration

\begin{abstract}
A simple procedure for regeneration of cucumber plants (Cucumis sativus L. cv. Poinsett 76) from cotyledon and hypocotyl explants has been developed. Somatic embryogenesis was induced on Murashige and Skoog (MS) salts and vitamins medium supplemented with 2,4-D at $2.0 \mathrm{mg} \cdot \mathrm{liter}^{-1}$ and kinetin at $0.5 \mathrm{mg} \cdot \mathrm{liter}^{-1}$. Development of embryos was accomplished on MS medium with NAA at $1.0 \mathrm{mg} \cdot \mathrm{liter}^{-1}$ and kinetin at $0.5 \mathrm{mg} \cdot \mathrm{liter}^{-1}$. Eighty-five percent of the mature somatic embryos formed showed a typical bipolar structure. All developed into morphologically normal plantlets when transferred to MS medium containing no growth regulators. Chemical name used: 2,4dichlorophenoxyacetic acid (2,4-D).
\end{abstract}

Previous reports have described procedures for cucumber plant regeneration from leaf callus (Malepszy and Nadolska-Orczyk, 1983; Nadolska-Orczyk and Malepszy, 1984), hypocotyl callus (Ziv and Gadasi, 1986), and cotyledon callus (Kim et al., 1988; Trulson and Shahin, 1986). However, these procedures had a low frequency of somatic embryogenesis and many abnormal embryos. The present report presents a simple and reliable method for the regeneration of fertile plants from hypocotyl- and cotyledon-derived callus cultures of 'Poinsett 76' cucumber via somatic embryogenesis.

Seeds of 'Poinsett 76' cucumber (Asgrow Seed, Kalamazoo, Mich.) were soaked in tap water for $» 15 \mathrm{~min}$. The seed coats were removed manually. The decoated seeds were surface-sterilized with $70 \%$ alcohpl for $1 \mathrm{~min}$. A 25 -rein treatment with $25 \%(\mathrm{v} / \mathrm{v})$ aqueous solution of Clorox followed. The seeds were then rinsed four times with sterile distilled water. Sterilized seeds. were germinated at $28 \mathrm{C}$ on $0.8 \%$ water agar (Difco) in darkness. Unless otherwise stated, all media were supplemented with $3 \%$ sucrose and solidified with $0.6 \%$ Phytagar (Gibco). The $\mathrm{pH}$ of all media was adjusted to 5.8 before autoclaving. All media were autoclave at $121 \mathrm{C}$ for $20 \mathrm{~min}$.

Three- to 5-day-old seedlings grown in vitro were used as donors of explants. Tissue sections from cotyledons, $5 \mathrm{~mm}^{2}$ in area, and segments of hypocotyl, 3 to $5 \mathrm{~mm}$ long, were used as explants. To determine the appropriate growth regulator composition for induction of embryogenic callus from explants, MS salts and vitamins medium (Murashige and Skoog, .1962) with $1.2 \mathrm{mg} 2,4,5-\mathrm{T}+$ $0.8 \mathrm{mg} \mathrm{BA} /$ liter (Malepszy and NadolskaOrczyk) arid 2,4-D (1.0, 2.0 mg.liter $\left.{ }^{-1}\right)+$

Received for publication 3 Oct. 1989. The cost of publishing this paper was defrayed in part by the payment of page charges. Under postal regulations, this paper therefore must be hereby marked advertisement solely to indicate this fact. kinetin $\left(0.5,1.0,2.0 \mathrm{mg} \cdot\right.$ liter $\left.^{-1}\right)$ were evaluated with 100 explants per treatment. Data were entered into a contingency table and $x^{2}$ values were computed.

Explants were placed on these induction media and the cultures incubated for 4 weeks at $26 \mathrm{C}$ in darkness. After 4 weeks the cultures were evaluated for the frequency and type of tissue produced. The callus cultures were then transferred to MS + NAA at 1.0 $\mathrm{mg} \cdot \mathrm{liter}^{-1}+$ kinetin at $0.5 \mathrm{mg} \cdot$ liter $^{-1}$. These cultures were incubated for an additional 2 weeks at $26 \mathrm{C}$ under diffuse cool-white fluorescent lamps $(4 \mathrm{klx})$ with a $16-\mathrm{hr}$ photoperiod. The tissues were then transferred to MS medium with no growth regulators for development of plantlets.

When plantlets developed an extensive root system on the latter medium, they were transplanted to pots containing planting medium and covered with plastic bags for hardening-off. Subsequently, the regenerated plants were potted in a mixture of 1 soil $: 1$ peatlite $(\mathrm{v} / \mathrm{v})$ and grown in a greenhouse.

Embryogenic callus tissues containing putative embryos were fixed in $10 \%$ neutral buffered formalin for 45 rein, dehydrated in ethyl alcohol-tertiary butyl alcohol series, and embedded in Paraplast (Monoject Scientific, St. Louis) at 56C. Embedded tissues were cut into 5- $\mu \mathrm{M}$-thick sections and stained for $12 \mathrm{hr}$ with $1 \%$ (v/v) safranin 0 (Sigma, St. Louis) dissolved in $50 \%$ alcohol, followed by a 20 -sec exposure to $1 \%(\mathrm{v} / \mathrm{v})$ fast green (Sigma) dissolved in 95\% alcohol.

Of all the growth regulator combinations evaluated, 2,4-D at $2.0 \mathrm{mg} \cdot$ liter $^{-1}+$ kinetin at $0.5 \mathrm{mg} \cdot \mathrm{liter}^{-1}$ had the highest induction frequency of embryonic callus tissue (Table 1). After 3 weeks of culture on this medium, $40 \%$ to $45 \%$ of the cotyledon and $25 \%$ of the hypocotyl explants formed different tissue morphologies. One particular type of tissue was translucent, smooth, and gelatinous. This tissue (Fig. 1) developed on the surface of the explants and where the explant was in contact with the medium.

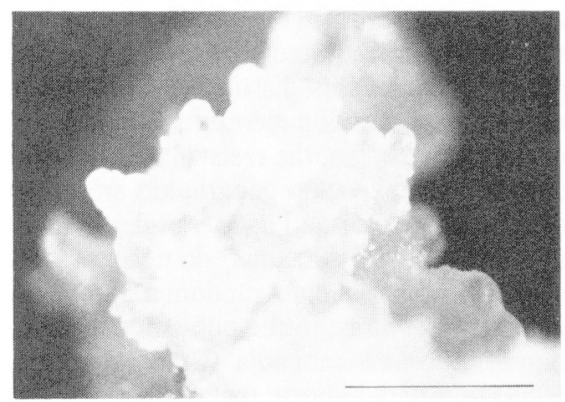

Fig. 1. Embryogenic callus derived from cotyledon explant after culture for 1 month on induction medium. Bar $=1.0 \mathrm{~mm}$.

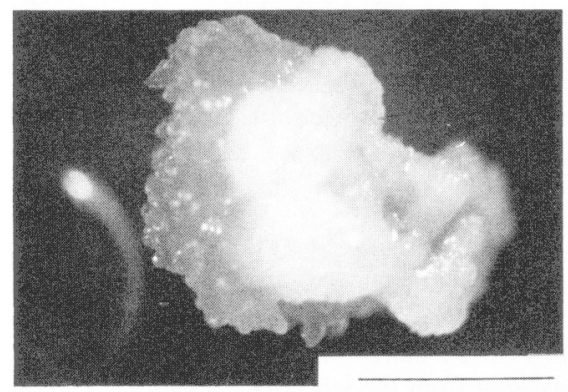

Fig. 2. Clusters of yellowish somatic embryos formed on the surface of gel-like callus after culture for 2 weeks on MS medium + NAA at $1.0 \mathrm{mg} \cdot$ liter $^{-1}+$ kinetin at $0.5 \mathrm{mg} \cdot$ liter $^{-1}$. Bar $=1.0 \mathrm{~mm}$.

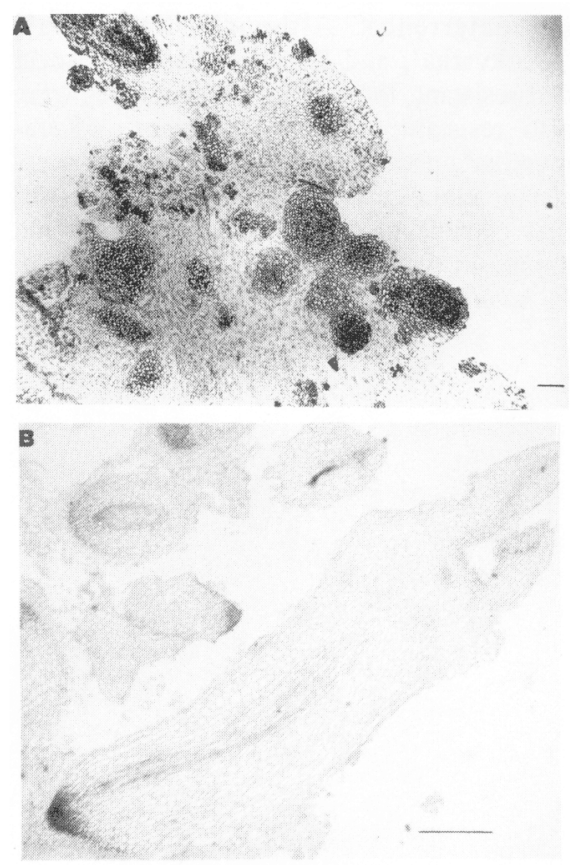

Fig. 3. (A) Section through an embryogenic callus tissue showing early multicellular stages of embryo differentiation. (B) Longitudinal section of a somatic embryo with bipolar structure. Bar $=375 \mu \mathrm{M}$.

The upper part of the gelatinous tissue contained small putative embryogenic tissues, which, upon microscopic examination, were found to consist of cytoplasmically dense, multicellular aggregates, resembling proembryonic masses. These aggregates later 


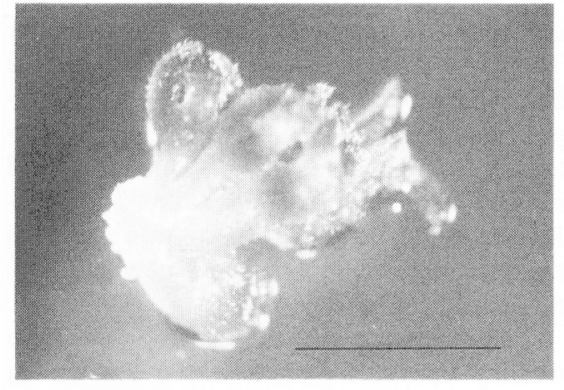

Fig. 4. A cluster of developing somatic embryos with will-developed cotyledons cultured on conversion medium. $\mathrm{Bar}=1.0 \mathrm{~mm}$.

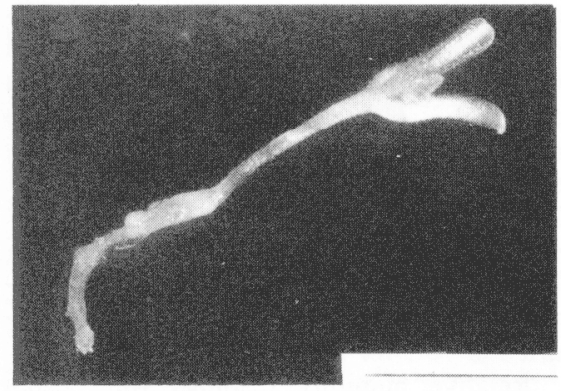

Fig. 5. A converted somatic embryo. Bar $=1.0$ $\mathrm{mm}$.

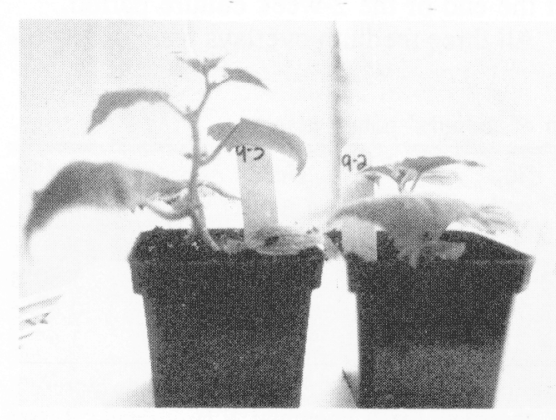

Fig. 6. Regenerated plants from somatic embryos 1 week after transplanting from Magenta boxes (Magenta Corp., Chicago) to planting medium.
Table 1. Effects of growth regulator composition on induction of somatic embryogenesis from cotyledon and hypocotyl explants.

\begin{tabular}{|c|c|c|c|}
\hline \multirow{2}{*}{\multicolumn{2}{|c|}{$\begin{array}{l}\text { Growth } \\
\text { regulators } \\
\left.\text { (mg-liter }{ }^{-1}\right)\end{array}$}} & \multicolumn{2}{|c|}{$\begin{array}{c}\text { Explants } \\
\text { producing } \\
\text { embryogenic } \\
\text { callus (\%) }\end{array}$} \\
\hline & & Cotyledons & Hypocotyl \\
\hline $2,4-\mathrm{D}$ & $\mathrm{KN}$ & & \\
\hline $\begin{array}{l}1.0 \\
1.0 \\
2.0 \\
2.0 \\
2.0\end{array}$ & $\begin{array}{l}0.5 \\
1.0 \\
0.5 \\
1.0 \\
2.0\end{array}$ & $\begin{array}{r}9 \\
9 \\
50 \\
1 \\
1 \\
1\end{array}$ & $\begin{array}{r}0 \\
0 \\
25 \\
0 \\
0\end{array}$ \\
\hline $2,4,5-\mathrm{T}$ & $\underline{\mathrm{BA}}$ & & \\
\hline 1.2 & 0.8 & $\begin{array}{c}2 \\
x^{2}=170.83^{*}\end{array}$ & $\begin{array}{c}0 \\
\chi^{2}=130.43^{* *}\end{array}$ \\
\hline
\end{tabular}

${ }^{7} \mathrm{KN}=$ kinetin, $\mathrm{BA}=6$-benzylaminopurine. **Significant at $P=0.01$.

organized into embryos. The embryogenic potential of the gelatinous callus tissue was not lost with successive subcultures on in-, duction medium for at least 6 months. In contrast to the gelatinous tissue, callus that was hard and nodular or white and friable was not found morphogenically competent.

After 4 weeks, the dense sectors were selected for transfer to maturation medium. Upon transfer, the putative proembryonic structures developed into yellowish embryolike structures (Fig. 2). A histological section of this embryonic callus tissue indicated a bipolar somatic embryo (Fig. 3). Formation of these structures was not synchronized across explants. The proembryonic tissue also proliferated, eventually forming a homogeneous mass of granular, yellow tissue.

The putative somatic embryos had a tendency to recallus when they were maintained on the conversion medium for more than 2 weeks. Therefore, after 2 weeks, the embryos were transferred to MS medium containing no growth regulators, where plantlet development followed (Figs. 4 and 5). About $80 \%$ to $85 \%$ of the embryos developed into phenotypically normal plantlets (Fig. 6).
Whole plants were able to flower and set seeds normally.

The combination of 2,4-D at $2.0 \mathrm{mg} \cdot$ liter $^{-1}$ and kinetin at $0.5 \mathrm{mg} \cdot$ liter $^{-1}$ also had an induction effect on mature cotyledons from dry seeds. However, the frequency of explants forming embryogenic callus was only $5 \%$.

This report presents a simple regeneration method for cucumber from seedling cotyledon and hypocotyl tissues. Cotyledons provided the best explant source. Regenerated plants can be obtained as early as 2 months after culture initiation. Cotyledons had proven to be an excellent source for transformation experiments in Arabidopsis thaliana (Schmidt and Willmitzer, 1988). This simple regeneration method has been applied in cucumber gene transfer experiments and regenerated transgenic plants have been obtained (unpublished data).

\section{Literature Cited}

Kim, S. G., J.R. Chang, H.C. Cha, and K.W. Lee. 1988. Callus growth and plant regeneration in diverse cultivars of cucumber (Cucumis sativus L.). Plant Cell, Tissue and Organ Culture 12:67-74

Malepszy S. and A. Nadolska-Orczyk. 1983. In vitro culture of Cucumis sativus. Z. Pflanzenphysiol. 111:273-276.

Murashige, T. and F. Skoog. 1962. A revised medium for rapid growth and bioassays with tobacco tissue cultures. Physiol. Plant. 15:473497.

Nadolska-Orczyk, A. and S. Malepszy. 1984 Cucumber plant regeneration from leaf explants-selected characteristics. Bul. Acad. Pol. Sci. Biol. 32:11-12.

Schmidt, R. and L. Willmitzer. 1988. High efficiency Agrobacterium fumefaciens- mediated transformation of Arabidopsis thaliana leaf and cotyledons explants. Plant Cell Rpt. 7:583-586.

Trulson, A.J. and E.A. Shahin. 1986. In vitro regeneration in the genus Cucumis. Plant Sci. 47:35-43.

Ziv, M. and G. Gadasi. 1986. Enhanced embryogenesis and plant regeneration from cucumber (Cucumis sativus L.) callus by activated charcoal in solid/liquid double-layer cultures. Plant Sci. 47:115-122. 